\title{
Pesticides in Ground Water - Niobrara and Weston Counties,
} Wyoming, 2005-2006

In 1991, members of local, State, and Federal governments, as well as industry and interest groups, formed the Groundwater and Pesticide Strategy Committee to prepare the State of Wyoming's generic Management Plan for Pesticides in Ground Water. Part of this management plan is to sample and analyze Wyoming's ground water for pesticides. In 1995, the U.S. Geological Survey, in cooperation with the Ground-water and Pesticide Strategy Committee, began statewide implementation of the sampling component of the State of Wyoming's generic Management Plan for Pesticides in Ground Water. During 2005-2006, baseline monitoring was conducted in Niobrara and Weston Counties. This Fact Sheet describes and summarizes results of the baseline monitoring in Niobrara and Weston Counties.

\section{Pesticides in Ground Water}

Synthetic organic pesticides are used to control weeds, insects, and other organisms in a wide variety of agricultural and nonagricultural settings. The use of pesticides has helped to make the United States the world's largest producer of food (Barbash and Resek, 1996). Pesticide use, however, also has been accompanied by concerns about potential adverse effects on the environment and human health. A potential pathway for the transport of pesticides is through hydrologic systems, which supply water for both humans and natural ecosystems. Water is one of the primary ways pesticides are transported from an application area to other locations

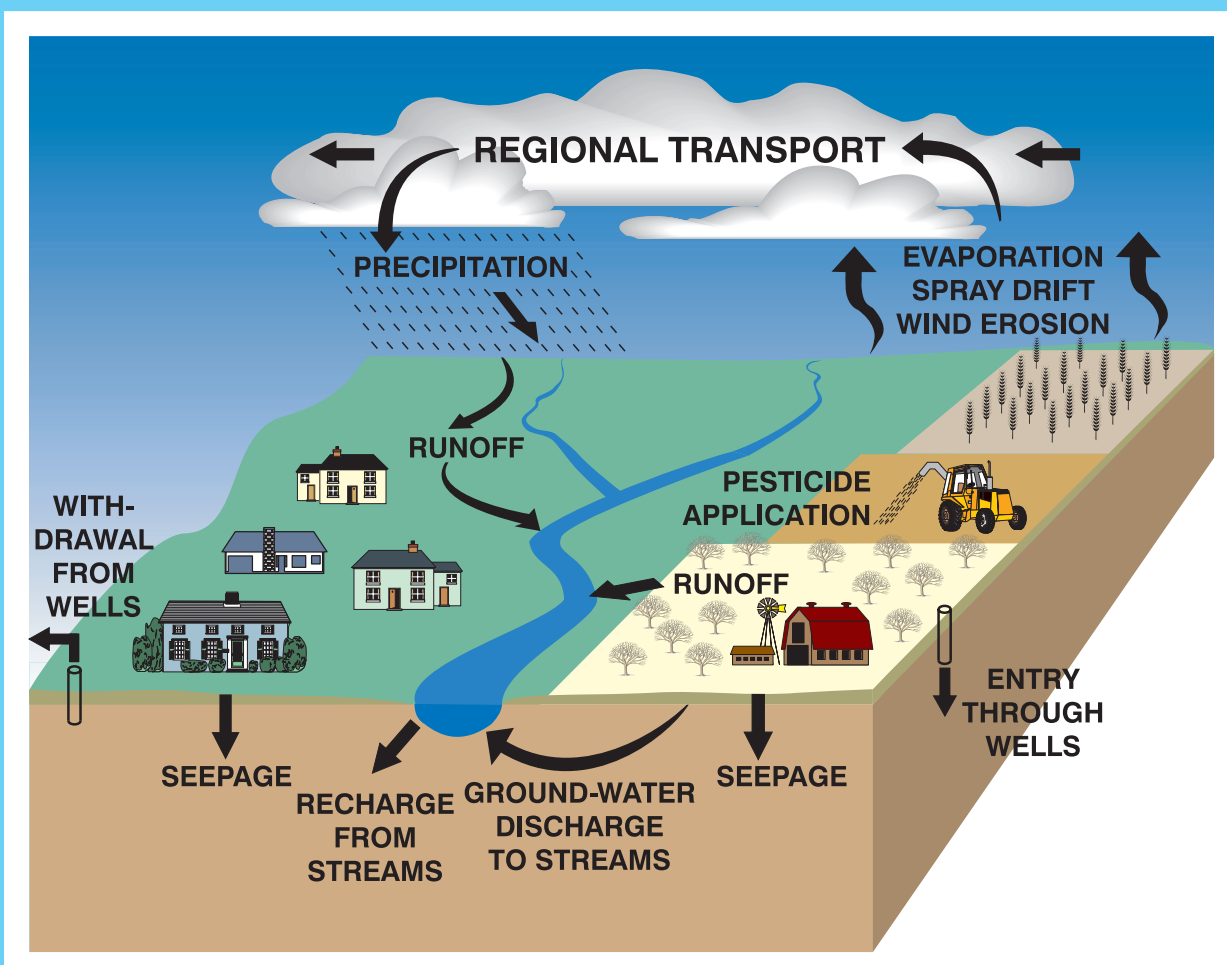

Figure 1. Pathways of pesticide movement in the hydrologic cycle (modified from Barbash and Resek, 1996).

in the environment (fig. 1) (Barbash and Resek, 1996).

Pesticide contamination of ground water is a national issue because of the widespread use of pesticides, the expense and difficulty of remediating ground water, and the fact that ground water is used for drinking water by about 40 percent of the Nation's population (Hutson and others, 2004). Although application rates and the variety of pesticides used may be greater in urban areas, concern over their presence in ground water is especially acute in rural agricultural areas where more than 95 percent of the population rely upon this resource for drinking water (Hutson and others, 2004).

\section{Wyoming's Pesticide Management Plan}

The Ground-water and Pesticide Strategy Committee (GPSC) has developed the generic State Management Plan for Pesticides in Ground Water (SMP) for the State of Wyoming (Wyoming Groundwater and Pesticides Strategy Committee, 1999). Wyoming was required by the U.S. Environmental Protection Agency to have an SMP in order for individuals and organizations to continue using certain pesticides in the State. The SMP includes information relating to individuals and organizations involved with implementation of the SMP, methods for preventing ground-water contamination, ground-water 
Table 1. Summary of pesticides and pesticide degradation products in ground-water samples from Niobrara and Weston Counties, September 2005 and April 2006.

[ $\mu \mathrm{g} / \mathrm{L}$, micrograms per liter; E, value is estimated; --, no data; C, estimated value used in calculation; NA, not applicable]

\begin{tabular}{|c|c|c|c|c|c|c|c|}
\hline Pesticide & $\begin{array}{l}\text { Pesticide } \\
\text { trade name }\end{array}$ & Pesticide action ${ }^{1}$ & $\begin{array}{c}\text { Number of } \\
\text { detections/ } \\
\text { number of } \\
\text { samples }^{2}\end{array}$ & $\begin{array}{c}\text { Minimum } \\
\text { reporting level }^{3} \\
(\mu \mathrm{g} / \mathrm{L})\end{array}$ & $\begin{array}{c}\text { Maximum } \\
\text { concentration } \\
(\mu \mathrm{g} / \mathrm{L})\end{array}$ & $\begin{array}{c}\text { Average } \\
\text { concentration } \\
\text { of detections } \\
(\mu \mathrm{g} / \mathrm{L})\end{array}$ & $\begin{array}{l}\text { Drinking- } \\
\text { water } \\
\text { standard }^{4} \\
(\mu \mathrm{g} / \mathrm{L})\end{array}$ \\
\hline \multicolumn{8}{|c|}{ Focal pesticides detected in ground water from Niobrara and Weston Counties } \\
\hline Atrazine & Aatrex & Selective herbicide & $2 / 22$ & 0.007 & E0.006 & C0.006 & 3 \\
\hline Bromacil & Hyvar XL & Herbicide & $3 / 22$ & .02 & E.4 & C.2 & 590 \\
\hline Clopyralid & Stinger, Curtail & Herbicide & $2 / 22$ & .02 & E.1 & C.1 & 61,000 \\
\hline Metsulfuron & Ally, Escort & Herbicide & $1 / 22$ & $.03, .07$ & E.03 & -- & NA \\
\hline Picloram & Tordon & Systemic herbicide & $2 / 22$ & .03 & 3 & 2 & 500 \\
\hline Simazine & Princep & Selective herbicide & $2 / 21$ & .005 & E.007 & C.006 & 4 \\
\hline \multicolumn{8}{|c|}{ Non-focal pesticides detected in ground water from Niobrara and Weston Counties } \\
\hline Diuron & Farmco, Durashield & Herbicide & $2 / 22$ & 0.02 & 0.05 & $\mathrm{C} 0.04$ & 510 \\
\hline Oryzalin & Surflan & Selective herbicide & $1 / 22$ & .01 & .6 & -- & NA \\
\hline Prometon & Pramitol & Non-selective herbicide & $4 / 21$ & .01 & .05 & .03 & 5100 \\
\hline \multicolumn{8}{|c|}{ Focal pesticides not detected in ground water from Niobrara and Weston Counties } \\
\hline \multicolumn{8}{|c|}{$\begin{array}{l}\text { Alachlor, Aldicarb, Aldicarb Sulfone }{ }^{7} \text {, Aldicarb Sulfoxide }{ }^{7} \text {, Cyanazine, 2,4-D, } \\
\text { DCPA, Dicamba, Dichloropropene, Hexazinone, Metolachlor, Metribuzin, Tebuthiuron }\end{array}$} \\
\hline \multicolumn{8}{|c|}{ Focal pesticides not analyzed in ground water from Niobrara and Weston Counties (no method of analysis available) } \\
\hline \multicolumn{8}{|c|}{ Difenzoquat } \\
\hline \multicolumn{4}{|c|}{$\begin{array}{l}{ }^{1} \text { Meister (2002). } \\
{ }^{2} \text { Each of the } 11 \text { wells was sampled twice. One well had only one analysis of } \\
\text { simazine and prometon. } \\
\text { }{ }^{3} \text { The minimum reporting level is the smallest concentration of a constituent that } \\
\text { may be reliably reported by using a given analytical method. The minimum } \\
\text { reporting level for metsulfuron was changed from } 0.03 \text { ug/L for late summer } \\
2005 \text { samples to } 0.07 \text { ug/L for the spring } 2006 \text { samples by the USGS National } \\
\text { Water Quality Laboratory. }\end{array}$} & \multicolumn{4}{|c|}{$\begin{array}{l}{ }^{4} \text { U.S. Environmental Protection Agency Maximum Contaminant Level unless } \\
\text { otherwise noted (U.S. Environmental Protection Agency, 2004). } \\
{ }^{5} \text { U.S. Environmental Protection Agency Lifetime Health Advisory Level } \\
\text { (U.S. Environmental Protection Agency, 2004). } \\
{ }^{6} \text { Bob Benson, U.S. Environmental Protection Agency, written commun., } \\
\text { December 30, } 2003 \text {. } \\
{ }^{7} \text { Degradation product of aldicarb. }\end{array}$} \\
\hline
\end{tabular}

monitoring, and the responses required if pesticides are detected in ground water.

One critical part of the SMP is groundwater monitoring. This ground-water monitoring program has two phases. The first phase, baseline monitoring, is designed to determine what pesticides, if any, have entered into a county's ground water. The second phase, problem identification monitoring, is used to gather additional information about ground water near wells with samples having significant pesticide detections.

Baseline monitoring is prioritized by a county rank and the vulnerability of the county's ground water to pesticide contamination. During the development of the SMP, the GPSC evaluated each county in Wyoming to determine the potential vulnerability of the county's ground water to pesticide contamination. Each county was ranked according to the extent of cropland and urban areas in the county, as well as to the amount of pesticides sold within the county in 1991 (Wyoming Ground-water and Pesticides Strategy Committee, 1999).
A ground-water vulnerability map was prepared for the uppermost or shallowest aquifers (Hamerlinck and Arneson, 1998). A Geographic Information System was used to overlay digital information about the hydrogeology and land use. Ground water can be vulnerable to contaminants because of either inherent sensitivity of the hydrogeology (such as a shallow water table or highly permeable aquifer materials) or the combination of the sensitivity and associated land use. The map was used to select monitoring sites in each county. The baseline monitoring focuses on areas where the ground water is most vulnerable (fig. 2).

The GPSC selected 18 pesticides and 2 degradation products as the focal pesticides to be analyzed for as part of the SMP (table 1). The analytical method used to detect the focal pesticides also can detect about 100 other pesticides and degradation products. Any additional pesticides that were detected are listed in table 1 as non-focal pesticides. Water from all wells in the baseline monitoring program was analyzed for the pesticides listed in table 1, with the exception of difenzoquat, for which analytical methods are not available.

The goal of the ground-water sampling part of the SMP is to collect groundwater samples for pesticide analyses in all 23 Wyoming counties. To date, sampling has been completed in these counties:

- 1995-1996: Goshen;

- 1997: Park;

- 1997-1998: Washakie;

- 1998-1999: Fremont, Lincoln, and Laramie;

- 1999-2000: Big Horn and Sheridan;

- 2000-2001: Platte, Johnson, and Crook;

- 2001-2002: Natrona, Sweetwater, and Teton;

- 2002-2003: Uinta;

- 2003-2004: Albany, Converse, and Hot Springs;

- 2004-2005: Carbon, Campbell, and Sublette;

- 2005-2006: Niobrara and Weston. 


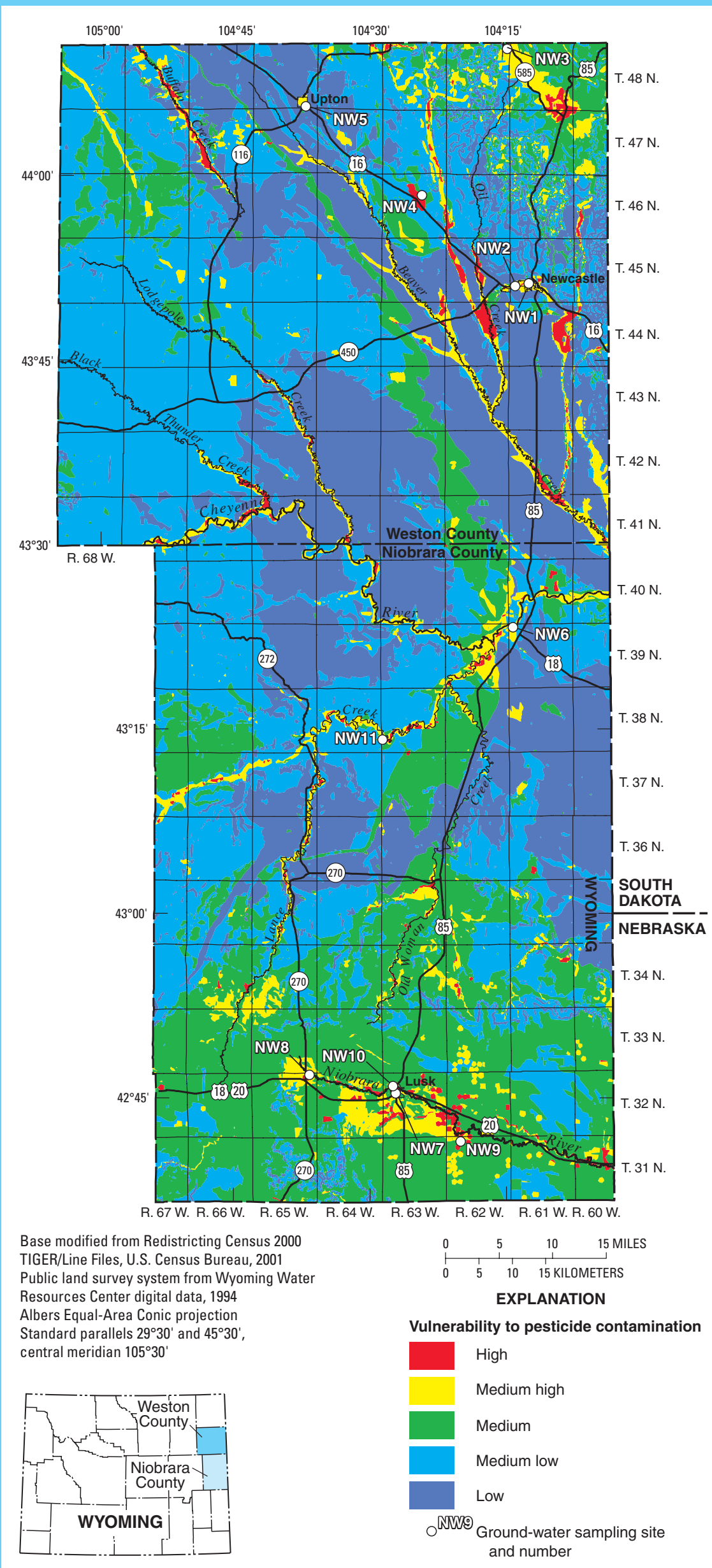

Figure 2. Vulnerability of ground water in Niobrara and Weston Counties, Wyoming, to pesticide contamination (from Hamerlinck and Arneson, 1998).
Ground-Water Monitoring in Niobrara and Weston Counties

Ground water in Niobrara County was ranked twenty-third and ground water in Weston County was ranked thirteenth most vulnerable to pesticide contamination in Wyoming (Wyoming Groundwater and Pesticide Strategy Committee, 1999). Because the land area in Niobrara and Weston Counties deemed vulnerable to ground-water pesticide contamination constituted a small fraction of the total land area, the GPSC combined the two counties into a single study. This facilitated location of suitable sampling sites, and was considered a reasonable compromise because of the similar geologic settings and land uses in the two counties. The vulnerability map by Hamerlinck and Arneson (1998) identifies unconsolidated Quaternary alluvial and terrace deposits in the counties and older consolidated units that underlie urban areas as the most vulnerable to pesticide contamination (shown as red or yellow on fig. 2).

Eleven wells were selected in Niobrara and Weston Counties (fig. 3) for baseline monitoring. All wells were located in areas that had high or medium high vulnerability to pesticide contamination (fig. 2). All wells were sampled twice, once in September 2005 and once in April 2006. Six of the 19 focal pesticides with available analyses and 3 non-focal pesticides were detected in the wells sampled (table 1). Pesticides were detected in 6 of the 11 wells sampled in Niobrara and Weston Counties (fig. 3); concentrations of each detected pesticide were equal to or less than $1 / 150$ of the applicable drinking-water standard (U.S. Environmental Protection Agency, 2004) (table 1).

The most commonly detected pesticide (4 of 21 samples) in Niobrara and Weston Counties was prometon. Prometon, the active ingredient in the general-use pesticide Pramitol, typically is detected in urban areas (Barbash and others, 1999). Prometon was the most commonly detected pesticide in Albany, Campbell, Carbon, Converse, Crook, Johnson, Natrona, Sheridan, Sublette, Teton, and Uinta Counties.

\section{Data Distribution and Availability}

Sampling results have been provided to local groups interested in pesticides in ground water in Niobrara and Weston Counties. The information can be used by citizens and local governments to help understand current (2005-2006) conditions. Analytical results of sampling in Niobrara and Weston Counties can be found in Blajszczak and others (2006) and U.S. Geological Survey (2007). All water-quality data for Wyoming can be found at $h$ ttp://waterdata.usgs.gov/wy/nwis/qwdata. Analytical results and Fact Sheets for all counties are available from the U.S. Geological Survey, 
Wyoming Water Science Center by phone, email, or the Internet at http://wy.water.usgs. gov/projects/pesticides/.

\section{References}

Barbash, J.E., and Resek, E.A., 1996, Pesticides in ground water-Distribution, trends, and governing factors: Chelsea, Mich., Ann Arbor Press, Pesticides in the Hydrologic System series, v. 2, 588 p.

Barbash, J.E., Thelin, G.P., Kolpin, D.W., and Gilliom, R.J., 1999, Distribution of major herbicides in ground water of the United States: U.S. Geological Survey WaterResources Investigations Report 98-4245, 64 p.

Blajszczak, E.J., Mason, J.P., Watson, K.R., Roberts, S.C., and Miller, K.A., 2006, Water-resources data, Wyoming, water year 2005, Volume 2. Ground water: U.S. Geological Survey Water-Data Report WY-05-2, 173 p.

Hamerlinck, J.D., and Arneson, C.S., eds., 1998, Wyoming ground water vulnerability assessment handbook, Volume 2. Assessing ground water vulnerability to pesticides: University of Wyoming, Laramie, Spatial Data and Visualization Center Publication SDVC 98-01-2, variable pagination.

Hutson, S.S., Barber, N.L., Kenny, J.F., Linsey, K.S., Lumia, D.S., and Maupin, M.A., 2004, Estimated use of water in the United States in 2000: U.S. Geological Survey Circular 1268, 46 p.

Meister, R.T., 2002, Farm chemicals handbook: Willoughby, Ohio, Meister Publishing Co., variable pagination.

U.S. Environmental Protection Agency, 2004, 2004 Edition of drinking water regulations and health advisories: EPA 822-R-04-005, 12 p., accessed September 16, 2006, at http://www.epa.gov/WaterScience/criteria/drinking/ dwstandards.pdf

U.S. Geological Survey, 2007, Water-resources data for the United States, Water Year 2006: U.S. Geological Survey Water-Data Report WDR-US-2006, accessed April 1, 2007, at http://pubs.water.usgs.gov/wdr2006

Wyoming Ground-water and Pesticides Strategy Committee, 1999, Wyoming generic state management plan for pesticides and ground water: prepared for Wyoming Department of Agriculture, Cheyenne, Wyoming, 103 p.

- Prepared by Cheryl A. Eddy-Miller

- Layout prepared by Suzanne C. Roberts

\section{For more information, contact:}

\section{Roy Reichenbach}

Wyoming Department of Agriculture

2219 Carey Avenue

Cheyenne, Wyoming 82002

(307) 777-6590

\section{Kevin Frederick}

Wyoming Department of Environmental Quality, Water Quality Division

Herschler Building West, 4th Floor

Cheyenne, Wyoming 82002

(307) 777-5985

\section{Cheryl A. Eddy-Miller}

\section{U.S. Geological Survey} 2617 E. Lincolnway, Suite B Cheyenne, Wyoming 82001 (307) 775-9167

Email: cemiller@usgs.gov

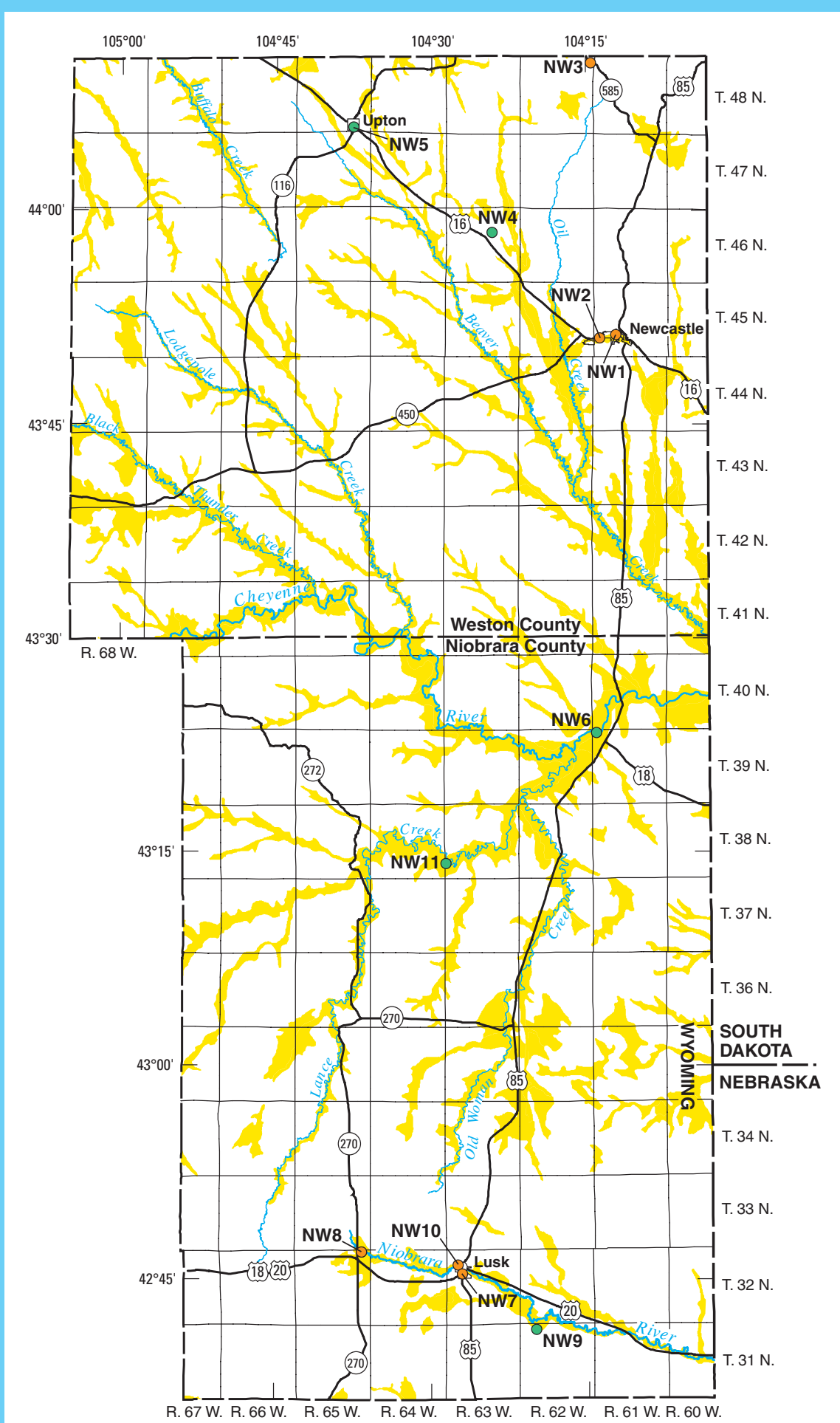

Base modified from Redistricting Census 2000

TIGER/Line Files, U.S. Census Bureau, 2001

Public land survey system from Wyoming Water Resources Center digital data, 1994 Albers Equal-Area Conic projection Standard parallels $29^{\circ} 30^{\prime}$ and $45^{\circ} 30^{\prime}$, central meridian $105^{\circ} 30$

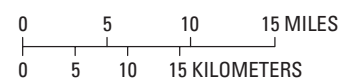

\section{EXPLANATION}

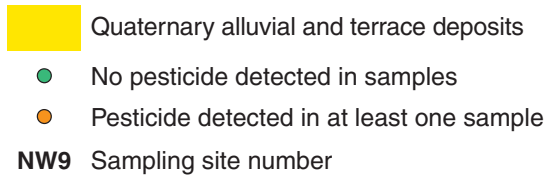

Figure 3. Location of wells sampled in Niobrara and Weston Counties, Wyoming, and notation of pesticide detection in samples from each well.
This Fact Sheet was prepared by the U.S. Geological Survey (USGS), the Wyoming Department of Agriculture (WDA), and the Wyoming Department of Environmental Quality, Water Quality Division (WDEQ). All agencies are members of the Ground-water and Pesticide Strategy Committee.
This project has been funded in part with a Section 319 grant from the U.S. Environmental Protection Agency to Wyoming Department of Environmental Quality's Non-Point Source Program.

The use of trade, product, industry, or firm names is for descriptive purposes only and does not imply endorsement by the U.S. Government. 